\title{
Beyin Ölümlü Adli Olgulardan Transplantasyon Amaçlı Organ Alımında Ortaya Çıkan Hukuki Sorunlar ve Adli Tip Açısından Önemi
}

\section{Emerging Legal Issues About Organ Transplantation from Forensic Cases Having Brain Death and Their Importance in Terms of Forensic Medicine}

\author{
Selma Tepehan ${ }^{1}$ Imdat Elmas ${ }^{2}$ Erdem Özkara \\ ${ }^{1}$ Trakya Üniversitesi Keșan Sağlı Yüksekokulu Hemșirelik Bölümü, Edirne \\ ${ }^{2}$ İstanbul Üniversitesi Adli Tip Enstitüsü, İstanbul \\ ${ }^{3}$ Dokuz Eylül Üniversitesi Tip Fakültesi Adli Tip Anabilim Dalı, İzmir
}

\section{Özet}

Amaç: Organ nakli birçok hasta için yaşamın belki de son seçeneği olarak oldukça önemlidir. En önemli organ kaynaklarından biri ise beyin ölümü gerçekleşen olgulardan yapılan nakillerdir. Bunların önemli bir kısmını ise adli olgular oluşturmaktadır. Bu çalışma adli olgulardan yapılan nakillerle ilgili sorunların ortaya konması amacıyla yapılmıştır. Olguların özellikleri ve konuyla ilgili tarafların görüşleri incelenmiştir.

Gereç ve Yöntem: Retrospektif tarama ve anket uygulaması olarak yapılan çalışmada; İstanbul Bölge Organ ve Doku Nakli Hizmetleri Koordinasyon Merkezi beyin ölümü bildirim formu ve diğer kayıtlarından 2005-2009 yılları arasında beyin ölümü gerçekleşmiş 810 olgu incelenmiştir. Anket çalışması; İstanbul Sağlık Müdürlüğü Genel Eğitim ve Araştırma Hastaneleri Yoğun Bakım Üniteleri’nde görev yapan gönüillü 279 hemşire ve 179 hekime uygulanmıştır.

Bulgular: İncelenen 810 olgunun 259 (\% 32.0)'unu adli olguların oluşturduğu görülmektedir. Donör olan beyin ölümlü 273 olguda, adli olgu oranı \%39.9'dur. Beyin ölümü gerçekleşmiş 109 adli olgu orijine göre incelediğinde; donör olan 44 (\%40.4) ve donör olmayan 58 (\%38.7) olguda birinci sırayı trafik kazaları aldığı, bunu donör olan 33 (\%30.2) ve donör olmayan 19 (\%12.7) oranla ateşli silah yaralanmalarının izlediği belirlenmiştir. Donör olan adli olguların savcı izni kayıtları incelendiğinde; sadece \%6 olguda kayıt olduğu görülmektedir. Anket çalışmamızda, hemşirelerin \%69.1’i, hekimlerin 74.1’i ülkemizde organ nakli ile ilgili yasada, adli olgulardan organ alınması koşullarını belirleyen ve mevcut eksiklikleri tamamlayan yeni yasal düzenlemelerin yapılması gerektiğine inandıklarını belirtmişlerdir.

Sonuç: Anket çalışmasına katılan sağlık çalışanlarının büyük çoğunlukla belirttikleri üzere ülkemizde adli olgulardan organ nakliyle ilgili koşulları belirleyen ve mevcut eksikleri tamamlayan yeni yasal düzenlemelere gereksinim vardır.

Anahtar kelimeler: Beyin ölümü, Adli olgu, Organ nakli, Otopsi.

\section{Giriş}

Sağlık Bakanlığı verilerine göre günümüzde 22.294 hasta böbrek, 577 hasta kalp, 2186 hasta karaciğer, nakil için bekleme listesinde yer almaktadır. Buna karşılık olarak 2014 yılında 2925 böbrek, 78 kalp, 1211 karaciğer nakli

Sorumlu yazar: Yrd.Doç.Dr. Selma Tepehan

Trakya Üniversitesi Keşan Sağlık Yüksekokulu

Hemșirelik Bölümü, Edirne

E-posta: selmatepehan@gmail.com

Geliş: 03.03.2015

Düzeltme: 15.04.2015

\section{Abstract}

Objective: Transplantation is very important for patients probably because it is their last chance to survive. Major sources of organs for transplantation are patients under treatment having brain death. Some of them are forensic cases. This study was conducted to reveal problems with transplantations from forensic cases. Characteristics of the cases and opinions of the parties about the subject were investigated.

Materials and Methods: In this retrospective study, data about 810 cases having brain death were obtained from Brain Death Forms completed in Istanbul Local Organ and Tissue Transplantation Coordination Department between 2005 and 2009. Data about opinions of 179 physicians and 279 nurses working in intensive care units of education and research hospitals in Istanbul were collected with a questionnaire.

Results: Out of 810 cases, 259 (32\%) were forensic cases. Of 273 cases that had brain death and were donors for transplantations, $39.9 \%$ were forensic cases. Of 109 forensic cases having brain death, 44 donors (40.4\%) and 58 non-donors (38.7\%) had traffic accidents and 33 donors (30.2\%) and 19 non-donors (12.7\%) had gunshot wounds. Permission for transplantation was obtained from the public prosecutor only in $6 \%$ of the donors. According to analyses of data from the questionnaire, $69.1 \%$ of the nurses and $74.1 \%$ of the physicians believed that new regulations determining criteria for organ transplantation from forensic cases and eliminating shortcomings of current laws should be adopted.

Conclusion: New laws are needed to determine criteria for transplantations from forensic cases and eliminate shortcomings of the currentlaws.

Keywords: Brain death, Forensic case, Organ transplantation, Autopsy.

gerçekleştirilmiştir. Donörlerin 3243'ü canlı, 407'si ise ölmüş bireylerdir (1).

Başka ülkelerde olduğu gibi ülkemizde de çok sayıda hasta organ nakli için sırada beklemekte, ancak temin edilen organ sayısı çok yetersiz kalmaktadır $(2,3)$. Organ temininde temel yaklaşım, tıbbi uygulamadaki beklentilerin yanı sıra, hukuki uygunluğun da sağlanmasıdır $(4,5)$. Organ temininde en önemli kaynağı solunum ve dolaşım fonksiyonları tıbbi destekle sürdürülen beyin ölümü tanısı almış olgular 
oluşturmaktadır (6). Bunların arasında adli olgular önemli bir yer teşkil etmektedir $(7,8)$. Bu durum, organ nakli amaçlı organ temininde adli boyutu olan olguların önemini artırmaktadır. Adli olgulardan organ alımının adli otopsi açısından yol açacağı olumsuzlukların iyi bilinmesi, bu sakıncaları ortadan kaldıracak tıbbi yaklaşım ve yasal düzenlemelerin geliştirilmesi, hem nakil amaçlı organ temini ve hem de adli tıp gereksinimleri açısından büyük önem taşımaktadır.

Bu çalışmada, adli boyutu olan olguların, organ donörü olan ve olmayan beyin ölümlü olgulardaki yeri ve önemi belirlenerek, yoğun bakım ünitelerinde çalışan hekim ve hemşirelerin başta tıbbi kayıtlar olmak üzere adli olgulardaki yaklaşımlarının mevcut yasal durum çerçevesinde irdelenmesi ve bu alanda yaşanan sorunların belirlenerek, çözüm önerilerinin geliştirilmesi amaçlanmıştır.

\section{Gereç ve Yöntem}

Çalışma, retrospektif bir tarama ve anket çalışması olarak uygulanmıştır (9). Retrospektif tarama; Sağlık Bakanlığı Tedavi Hizmetleri Genel Müdürlüğü İstanbul Bölge Organ ve Doku Nakli Hizmetleri Koordinasyon Merkezi beyin ölümü bildirim formu ve diğger kayıtlarından 2005-2009 yılları arasında beyin ölümü gerçekleşmiş 810 olgunun, beyin ölümü ve organ nakli ile ilgili verilerinin alınıp istatistiki olarak incelenmesiyle yapılmıştır. Bu verilerden; beyin ölümü gerçekleşmiş olgular, bu olgular arasında adli vakaların yeri ve nitelikleri, beyin ölümü gerçekleşmiş adli olguların orijinine göre dağılımı, donör olan adli olguların savcı izni kayıtları değerlendirmeye alınmıştır. Anket çalışması; İstanbul Sağlık Müdürlüğü Genel Eğitim ve Araştırma Hastaneleri Yoğun Bakım Ünitelerinde (YBÜ) görev yapan gönüllü 279 hemşire ve 179 hekime uygulanmıştır. Katılımcılara, 28 sorudan oluşan anket formuyla, adli olgulardan organ alımı, cezai ve hukuki mevzuat konusunda bilgi ve yaklaşımları sorgulanmıştır.

\section{Bulgular}

Sağlık Bakanlığg Tedavi Hizmetleri Genel Müdürlüğü İstanbul Bölge Organ ve Doku Nakli Hizmetleri Koordinasyon Merkezi beyin ölümü bildirim formu ve diğer kayıtları incelendiğinde, 2005-2009 yılları arasında beyin ölümü gerçekleşmiş 810 olgununun 259 (\% 32.0)'unu adli olguların

Tablo 1. 2005-2009 yılları arasında beyin ölümü gerçekleşmiş olguların, adli olgu durumlarına göre dağılımı.

\begin{tabular}{|c|l|cc|cc|cr|}
\hline & & \multicolumn{2}{|c|}{} & \multicolumn{2}{c|}{$\begin{array}{c}\text { Donör } \\
\text { Olmayan }\end{array}$} & \multicolumn{2}{c|}{ Toplam } \\
\cline { 3 - 8 } & \multirow{2}{*}{ Adli Olgu Durumu } & $\mathbf{n}$ & $\%$ & $\mathbf{n}$ & $\%$ & $\mathbf{n}$ & $\%$ \\
\hline \multirow{3}{*}{ Donör } & Adli olgu olan & 109 & 39.9 & 150 & 27.9 & 259 & 32.0 \\
olan & Adli olgu olmayan & 89 & 32.6 & 174 & 324 & 263 & 32.5 \\
& Belirsiz & 75 & 27.5 & 213 & 39.7 & 288 & 35.5 \\
& Toplam & $\mathbf{2 7 3}$ & $\mathbf{1 0 0}$ & $\mathbf{5 3 7}$ & $\mathbf{1 0 0}$ & $\mathbf{8 1 0}$ & $\mathbf{1 0 0}$ \\
\hline
\end{tabular}

Tablo 2. Beyin ölümü gerçekleşmiş adli olguların orijinine göre dağılımı.

\begin{tabular}{|c|c|c|c|c|c|c|}
\hline \multirow[t]{2}{*}{ Adli Olgu Orijini } & \multicolumn{2}{|c|}{ Donör Olan } & \multicolumn{2}{|c|}{ Donör Olmayan } & \multicolumn{2}{|c|}{ Toplam } \\
\hline & $\mathbf{n}$ & $\%$ & $\mathbf{n}$ & $\%$ & $\mathbf{n}$ & $\%$ \\
\hline Ateşli Silah Yaralanması & 33 & 30.2 & 19 & 12.6 & 52 & 20.0 \\
\hline Kesici-Delici Alet Yaralanması & 3 & 2.8 & 1 & 0.7 & 4 & 1.5 \\
\hline Trafik Kazası & 44 & 40.4 & 58 & 38.6 & 102 & 39.4 \\
\hline İntoksikasyon & 6 & 5.5 & 4 & 2.7 & 10 & 3.9 \\
\hline Ass-Asfiksi & 1 & 0.9 & 1 & 0.7 & 2 & 0.8 \\
\hline Yüksekten Düşme & 11 & 10.1 & 18 & 12 & 29 & 11.2 \\
\hline Yabancı cisim aspirasyonu & -- & - & 1 & 0.7 & 1 & 0.4 \\
\hline Kayit olmayan & 11 & 10.1 & 48 & 32 & 59 & 22.8 \\
\hline Toplam & 109 & 100 & 150 & 100 & 259 & 100 \\
\hline
\end{tabular}


oluşturduğu görülmektedir. Donör olan beyin ölümlü 273 olguda, adli olgu oranı \%39.9'dur. Adli olgu olup olmadığı

Tablo 3. Beyin ölümü gerçekleşmiş donör olan adli olguların savcı izni kayıt durumlarına göre dağılımı.

\begin{tabular}{|l|cc|}
\hline \multirow{2}{*}{ Savc1 izni (Donör) } & \multicolumn{2}{|c|}{ Toplam } \\
\cline { 2 - 3 } & $\mathbf{n}$ & \% \\
\hline Kayıt var & 6 & 5.5 \\
Kayit yok & 103 & 94.5 \\
Toplam & $\mathbf{1 0 9}$ & $\mathbf{1 0 0}$ \\
\hline
\end{tabular}

konusunda kayıt bulunmayan 288 (\%35.5) olgunun bir kısmının adli olgu kapsamında olduğu tahmin edilmektedir (Tablo 1). Beyin ölümü gerçekleşmiş 109 adli olgu orijine göre incelediğinde; donör olan 44 (\%40.4) ve donör olmayan 58 (\%38.7) olguda birinci sırayı trafik kazaları aldığı, bunu donör olan 33 (\%30.2) ve donör olmayan 19 (\%12.7) olguda ateşli silah yaralanmalarının izlediği belirlenmiştir (Tablo 2). Donör olan adli olguların savc1 izni kayıtları incelendiğinde; sadece \%6 olguda kayıt olduğu, buna karşın \%94 olguda kayıt olmadığ1 görülmektedir (Tablo 3).

Tablo 4. Anket uygulanan katılımcıların ilgili birimlere göre dağılımı.

\begin{tabular}{|c|c|c|c|c|}
\hline \multirow[b]{2}{*}{ Çalıșılan Birim } & \multicolumn{2}{|c|}{ Hemșire } & \multicolumn{2}{|c|}{ Hekim } \\
\hline & $\mathbf{n}$ & $\%$ & $\mathbf{n}$ & $\%$ \\
\hline Anesteziyoloji ve Reanimasyon YBÜ & 129 & 46.2 & 108 & 60.3 \\
\hline Koroner YBÜ & 52 & 18.7 & 15 & 8.4 \\
\hline Kalp ve Damar Cerrahisi YBÜ & 16 & 5.7 & 12 & 6.7 \\
\hline Nöroloji YBÜ & 19 & 6.8 & 10 & 5.6 \\
\hline Nöroşirurji YBÜ & 12 & 4.3 & 13 & 7.3 \\
\hline Yenidoğan - Çocuk/YBÜ & 51 & 18.3 & 21 & 11.7 \\
\hline Toplam & 279 & 100 & 179 & 100 \\
\hline
\end{tabular}

Tablo 5. Adli olgulardan organ alımına ilişkin eksiklikleri giderici yeni yasal düzenlemeler yapılmasına ilişkin hemşire ve hekimlerin yaklaşımı.

\begin{tabular}{|c|c|c|c|c|c|c|}
\hline \multirow{2}{*}{$\begin{array}{l}\text { Ülkemizde organ nakli ile ilgili yasada, } \\
\text { adli olgulardan organ alınması } \\
\text { koşullarını belirleyen ve mevcut } \\
\text { eksiklikleri tamamlayan yeni yasal } \\
\text { düzenlemelerin yapılması gerektiğine } \\
\text { inanıyor musunuz? }\end{array}$} & \multicolumn{2}{|c|}{ Hemşire } & \multicolumn{2}{|c|}{ Hekim } & \multirow[b]{2}{*}{$\mathbf{x}^{2}$} & \multirow[b]{2}{*}{$\mathbf{p}$} \\
\hline & $\mathbf{n}$ & $\%$ & $\mathbf{n}$ & $\%$ & & \\
\hline Evet & 188 & 69.1 & 129 & 74.1 & 3.67 & 0.16 \\
\hline Hayır & 19 & 7 & 16 & 9.2 & & \\
\hline Fikrim yok & 65 & 23.9 & 29 & 16.7 & & \\
\hline
\end{tabular}

Tablo 6. Adli olgulardan organ alımına ilişkin eksiklikleri giderici yeni yasal düzenlemeler yapılmasına ilișkin Hemşirelerin çalıştıkları yoğun bakım ünitelerine göre yaklaşımı.

\begin{tabular}{|c|c|c|c|c|c|c|c|c|}
\hline \multirow{2}{*}{$\begin{array}{l}\text { Ülkemizde organ nakli ile ilgili yasada, } \\
\text { adli olgulardan organ alınması } \\
\text { koşullarını belirleyen ve mevcut } \\
\text { eksiklikleri tamamlayan yeni yasal } \\
\text { düzenlemelerin yapılması gerektiğine } \\
\text { inanıyor musunuz? }\end{array}$} & \multicolumn{2}{|c|}{ Reanimasyon } & \multicolumn{2}{|c|}{$\begin{array}{c}\text { Yenidoğan- } \\
\text { Çocuk }\end{array}$} & \multicolumn{2}{|c|}{ Diğer $^{++}$} & \multirow[b]{2}{*}{$\mathbf{x}^{2}$} & \multirow[b]{2}{*}{ p } \\
\hline & $\mathbf{n}$ & $\%$ & $\mathbf{n}$ & $\%$ & $\mathbf{n}$ & $\%$ & & \\
\hline Evet & 89 & 70.6 & 33 & 68.8 & 66 & 67.3 & 0.47 & 0.976 \\
\hline Hayır & 8 & 6.3 & 3 & 6.3 & 8 & 8.2 & & \\
\hline Fikrim yok & 29 & 23 & 12 & 25 & 24 & 24.5 & & \\
\hline
\end{tabular}

${ }^{++}$Koroner, Nöroloji ve Nöroşirurï Yoğun Bakım 
Tablo 7. Adli olgulardan organ alımına ilişkin eksiklikleri giderici yeni yasal düzenlemeler yapılmasına ilişkin hekimlerin uzmanlık alanlarına göre yaklaşımı.

\begin{tabular}{|c|c|c|c|c|c|c|c|c|}
\hline \multirow{2}{*}{$\begin{array}{l}\text { Ülkemizde organ nakli ile ilgili } \\
\text { yasada, adli olgulardan organ } \\
\text { alınması koşullarını belirleyen } \\
\text { ve mevcut eksiklikleri } \\
\text { tamamlayan } \\
\text { yeni yasal düzenlemelerin } \\
\text { yapılması gerektiğine inanıyor } \\
\text { musunuz? }\end{array}$} & \multicolumn{2}{|c|}{$\begin{array}{l}\text { Anesteziyoloji ve } \\
\text { Reanimasyon }\end{array}$} & \multicolumn{2}{|c|}{$\begin{array}{l}\text { Yenidoğan- } \\
\text { Çocuk }\end{array}$} & \multicolumn{2}{|c|}{ Diğer $^{++}$} & \multirow[b]{2}{*}{$\mathbf{x}^{2}$} & \multirow[b]{2}{*}{$\mathbf{p}$} \\
\hline & $\mathbf{n}$ & $\%$ & $\mathbf{n}$ & $\%$ & $\mathbf{n}$ & $\%$ & & \\
\hline Evet & 79 & 76.7 & 11 & 52.4 & 39 & 78 & 12.17 & $0.016^{*}$ \\
\hline Hayır & 11 & 10.7 & 1 & 4.8 & 4 & 8 & & \\
\hline Fikrim yok & 13 & 12.6 & 9 & 42.9 & 7 & 14 & & \\
\hline
\end{tabular}

${ }^{++}$Kardiyoloji, Nöroloji ve Nöroşirurii

Tablo 8. Hemşire ve hekimlerin beyin ölümü ve organ nakli ile ilgili ülkemizdeki mevcut hukuki düzenlemeleri yeterli bulma durumları.

\begin{tabular}{|c|c|c|c|c|c|c|}
\hline \multirow[t]{2}{*}{$\begin{array}{l}\text { Beyin ölümü gerçekleşmiş olgulardan organ } \\
\text { alımına olanak sağlayan ülkemizdeki mevcut } \\
\text { hukuki düzenlemeleri yeterli buluyor } \\
\text { musunuz? }\end{array}$} & \multicolumn{2}{|c|}{ Hemşire } & \multicolumn{2}{|c|}{ Hekim } & \multirow[b]{2}{*}{$\mathrm{x}^{2}$} & \multirow[b]{2}{*}{ p } \\
\hline & $\mathbf{n}$ & $\%$ & $\mathbf{n}$ & $\%$ & & \\
\hline Yeterlidir & 43 & 15.9 & 34 & 19.8 & 1.59 & 0.452 \\
\hline Değiştirilmesi ve geliştirilmesi gerekmektedir & 165 & 61.1 & 105 & 61 & & \\
\hline Fikrim yok & 62 & 23 & 33 & 19.2 & & \\
\hline
\end{tabular}

\section{Tartışma ve Sonuç}

Retrospektif taramada, organ donörü olan beyin ölümlü olguların \%39.9, donör olmayan olguların ise $\% 27.9$ kadarını adli olgular oluşturduğu, olguların \%35.5’inde ise adli olgu olup olmadığı belirtilmediği belirlenmiştir (Tablo 1). Özellikle donör olan olgularda adli olgu oranının yüksek olması, organ alınması için uygulanan cerrahi girişimin adli tıp uygulamasıyla çelişmeyen bir yaklaşımla gerçekleştirilmesini zorunlu hale getirmektedir. Adli olgulardan organ alınmasina adli tıp uzmanlarının yaklaşımını ve önerilerini belirlemek amacıyla yapılan bir çalışmada; adli tıp uzmanlarının \%84.4'ü otopsi öncesi organ alınmasının ölüm mekanizmasını aydınlatmada etkili olabilecek bazı bulguların kaybolma riskine yol açabileceğini, \%74'ü bazı olgularda ölüm mekanizmasını aydınlatıcı otopsi tekniklerinin uygulanma olanağını ortadan kaldırabileceğini, \%93.5'i adli otopsiyi etkilemeyecek organların alınabileceğini, \%6.5'i adli olgulardan, transplantasyon amaçlı organ alınmasına tamamen karşı çıktığını belirtmişlerdir (10).

Dış bir etki sonucu hayatını kaybeden bir kimseden (adli olgudan) organ ya da doku alınırken iki nokta önem kazanmaktadır. Bunlardan birincisi, alınacak olan organ ya da dokunun görev yapma kabiliyetini önemli ölçüde kaybetmemesi için bir an önce çıkarılması, ikincisi de, bu operasyon yapılırken ölümün nedenini izah edecek bulgu ve delillerin kaybolmamasıdır. Kușkusuz adli olgulardan organ alınabilmesi için, onamın yanı sıra savcı izninin alınması önemli ve kaçınılmaz bir sorumluluktur. Beyin ölümü tanısının kesinleşmesinden sonra solunum ve dolaşım desteğinin sürdürülmesine rağmen, geçen zaman ile orantılı olarak, organ ve dokularda hücresel ölümün yaygınlaşması kaçınılmaz bir durumdur. Bu nedenle savcı izninin bir an önce elde edilmesi, organ naklinin başarısı açısından büyük önem taşımaktadır. Organ nakli operasyonlarının yaşam kurtarıcı bir girişim olduğu dikkate alındığında, bu alandaki yasal yetersizliklerin bir an önce giderilmesinin gerekliliği ortaya çıkmaktadır (11).

Organ nakli amaçlı karaciğer ve böbreklerin çıkarılması girişimi sonucu, batında yer işgal eden organlar önemli ölçüde karışmakta ve büyük damarların kesilmesi sonucu peritoneal boşlukta büyük miktarda serbest kan toplanmaktadır. Benzer durum kalp ve akciğerlerin çıkarılması sonucu göğüs boşluğunda da kaçınılmaz bir şekilde gerçekleşmektedir (12). Bu durum adli amaçli otopsi uygulamasında önemli zorluklara ve olumsuzluklara yol açmaktadır. Konuyla ilgili yapılan bir anket çalışmasında, ankete katılan adli tıp uzmanlarının \%83.1i ve diğer hekimlerin ise \%87.0', adli tıp açısından ortaya çıkan bu olumsuzlukları gidermek için, organ alınması için yapılan cerrahi girişim esnasında, bir adli tıp uzmanının da gözlemci 
olarak hazır bulunmasını ve adli otopsi açısından önemli olabilecek bulguları rapor haline dönüştürerek, bu raporun otopsi yapacak merkeze gönderilmesi gerektiğini önermiştir (10). Diğer taraftan donör olan adli olguların savcı izni kayıtları incelendiğinde; sadece \%6 olguda kayıt olduğu, buna karşın \%94 olguda kayıt bulunmadığı görülmektedir. Düzenli kayıt sistemi ile bu belirsizliğin ortadan kaldırılması, sonradan ortaya çıkabilecek adli soruşturmalar bakımından önem taşımaktadır.

2238 sayılı Organ ve Doku Alınması, saklanması, aşılanması ve Nakli Hakkında Kanun'da adli olgulardan hangi koşullarda organ ve doku alınabileceğine dair detaylı bir açıklama bulunmamaktadır. Kanunun 14. maddesinde değişiklik yapan 2594 sayılı kanuna göre kaza ve doğal afetler sonucu gelişen ölümlerde ivedilik halinde organ alınabileceğini ve adli otopsinin bu işlemler tamamlandıktan sonra yapılacağı ve hekimler kurulunun raporu adli muayene ve otopsi tutanağına geçirileceği belirtilmektedir (13). Ancak bu yaklaşım sadece özel bir durum için düzenlenmiş olup, ihtiyacı karşılamaktan uzaktır. Anket çalışmamızda, hemşirelerin \%69.1'i, hekimlerin 74.1'i ülkemizde organ nakli ile ilgili yasada, adli olgulardan organ alınması koşullarını belirleyen ve mevcut eksiklikleri tamamlayan yeni yasal düzenlemelerin yapılması gerektiğine inandıklarını belirtmişlerdir. $\mathrm{Bu}$ yaklaşım, hemşire ve hekimlerin kendi içinde çalıştıkları birimlere göre sorgulandığında, organ alınım kararının en sık verildiği Anesteziyoloji ve Reanimasyon YBÜ'de çalışan hekimlerde, adli olgulardan organ alınması koşullarını belirleyen ve mevcut eksiklikleri tamamlayan yeni yasal düzenlemelerin yapılması gerekliliğinin \%61 gibi anlamlı derecede yüksek oranda benimsendiği görülmektedir

Adi olguların orijinini incelendiğinde; birinci sırayı trafik kazaları oluşturmakta olup, bunu ateşli silah yaralanması, yüksekten düşme ve diğer adli olgular izlemektedir. Ancak donör olan olguların \%10.1’inde, donör olmayan olguların ise \%32'sinde adli olguların orijinine ilişkin herhangi bir kayıt bulunmamaktadır. Kayıtlardaki bu yetersizlik, hukuki açıdan adli olguların öneminin yeterince kavranmadığını göstermektedir. Konuyla ilgili Elazı̆̆'da yapılan bir çalışmada il ve çevresinde 2001-2007 yılları arasında meydana gelen 0-18 yaş grubundaki 178 adli ölüm olgularının ölü muayenesi ve otopsileri yapılarak ölüm özellikleri incelenmiştir. Çalışmamızda ulaşmış olduğumuz sonuçla uyumlu olarak ilk sırada 43 olgu (\%24.1) ile trafik kazaları, ikinci sırada 34 olgu (\%19.1) ile suda boğulma ve üçüncü sırada 24 olgu (\%13.4) yüksekten düşme sonucu ölümler gelmektedir (14). Kayseri'de yapılan diğer bir çalışmada ölü muayenesi ve otopsisi yapılan 482 olgunun 212'si trafik kazası 57'si yüksekten düşme, 39’u ateşli silah yaralanması, 22 si ise intihar'dır (15).
Konya'da 2001-2006 yılları arasında meydana gelen 0-18 yaş grubu adli ölüm olgularının özelliklerinin belirlenmesi amacıyla yapılan çalışmada ise 560 adli ölüm olgusunun 493’ünün orijini kaza, 42 olgunun cinayet, 15 olgunun orijinin ise intihar olduğu belirtilmiştir (16).

Günümüzde organ nakli, kronik organ yetmezliği tablosunda olan hastalar için kaçınılmaz tedavi yöntemi olarak önemini korumakta, buna karşın birçok hasta organ temin edilememesi nedeniyle yaşamını kaybetmektedir. Beyin ölümlü Adli olgulardan nakil amaçlı organ alınmasını engelleyen herhangi bir yasal düzenleme bulunmamakla birlikte, organ alımı girişiminin adli süreci olumsuz yönde etkilememesi aranan bir ön koşuldur. Bu nedenle, adli olgulardan organ alınımına ilişkin prosedürlerin açıkça tanımlanması, bu alandaki tereddüt ve olumsuzlukları ortadan kaldıracak ve sürecin güvenliğini de gözeterek hızlandıracak yasal düzenlemelerin geciktirilmeden oluşturulması, organ bekleyen hastalar ve adli tıp gereksinimleri açısından önemini korumaktadır.

\section{Kaynaklar}

1. Sağlık Bakanlığ $\breve{1}_{1}$ Organ, Doku Nakli ve Diyaliz Hizmetleri Daire Başkanlığı, https://organ.saglik.gov.tr/web/Default.aspx, Erișim tarihi; 27 Şubat 2014

2. Sağlık Bakanlığı, Beyin Ölümü Bildirimlerinin ve Kadavra Organ Bağışının Arttırılması Genelgesi, http://www.saglik.gov.tr/TR/ belge/1-7317/beyin-olumu-bildirimlerinin-ve-kadavra-organbagisinin-.html, Erişim tarihi; 26 Kasım 2011.

3. Kapuağası A. Beyin ölümü artıyor ama organ nakli azalıyor. Medimagazin Gazetesi, 06.10.2011.

4. Atamer Yeşim M. Ölüden organ naklinin beraberinde getirdiği bazı hukuki sorunlar. Milletlerarası Hukuk ve Milletlerarası Özel Hukuk Bülteni. 1999-2000; 19(1-2) : 115-159.

5. Koçak Süren S. Organ ve doku naklinin yasal ve etik açıdan incelenmesi. Türkiye Barolar Birliği Dergisi. 2007;73:174-195.

6. Aksoy Ş. Kadavradan organ bağışını artırmaya yönelik bir öneri. Türkiye Klinikleri Tıp Etiği Hukuku ve Tarihi Dergisi. 2003;11(3):189-194.

7. İzdeş S, Erkılıç E. Beyin ölümü. Turkish Medical Journal. 2007;1:173-179.

8. Elmas İ, Tüzün B, Aydın AE. The evaluation of the brain death in cases admitted to the organ transplantation unit of the İstanbul University, İstanbul Faculty of Medicine between 1989-1998. Medical Bulletin İstanbul Medical Faculty. 2000;33(2):138-142.

9. Tepehan S. Beyin ölümü ve organ naklinin sağlı personeli ve hukuki mevzuat açısından incelenmesi. Doktora Tezi, 2012.

10. Elmas I, Tüzün B, Akkay E. Adli otopsi öncesi transplantasyon amaçlı organ alınmasına hekimlerin yaklaşımı: Anket çalışması. Adli Tip Bülteni. 1998; 3(2):51-56.

11. Artuk ME, Gökcen A, Yenidünya AC. Ceza Hukuku genel hükümler I. 3. baskı. Ankara: Seçkin Yayıncılık, 2002:482-494. 485 (482-486)

12. Gresham GA, Turner AF. Post-mortem procedures (An illustrated textbook). London: Wolfe Medical Publications Ltd., 1979:118-9.

13. Organ ve Doku Alınması, saklanması, aşılanması ve Nakli Hakkında Kanun, http://www.resmigazete.gov.tr/eskiler/2014/01/ 20140118.pdf, erişim tarihi; 27 Şubat 2014.

14. Tokdemir M, Kafadar H, Düzer S. Elazığ'da 2001-2007 yılları arasında otopsisi yapılan 0-18 yaş arası olguların değerlendirilmesi. FrratTip Dergisi.2009; 14(2):111-114. 
15. Yağmur F, Din H. Kayseri ilinde 2007 yılında adli ölü muayenesi ve otopsileri yapılan olguların değerlendirilmesi. Adli Tıp Dergisi. 2009; 23(2):18-24.
16. Demirci Ş, Doğan KH, Erkol Z, Deniz İ. Konya'da 2001-2006 yılları arasında meydana gelen 0-18 Yaş grubu ölümler. Türkiye Klinikleri Adli Tip Dergisi. 2007; 4(3):12 